\title{
Sistem Pakar Berbasis Android Diagnosis Penyakit Hepatitis Menggunakan Metode Certainty Factor dengan Penelusuran Forward Chaining
}

\author{
Intan Permata Sari ${ }^{\# 1}$, Agus Priyanto ${ }^{\# 2}$, Ridho Ananda ${ }^{\# 3}$ \\ ${ }^{\#}$ Institut Teknologi Telkom Purwokerto \\ Jl.D.I. Panjaitan No.128, Purwokerto Kidul, Purwokerto Sel., Purwokerto, Jawa Tengah 53147 \\ 1161020890ittelkom-pwt.ac.id \\ 2agus_priyantodittelkom-pwt.ac.id \\ ${ }^{3}$ ridho@ittelkom-pwt.ac.id
}

\begin{abstract}
Abstrak — Salah satu penyakit menular pembunuh terbesar setelah tuberculosis yaitu penyakit hepatitis. Di Indonesia penyakit hepatitis sudah tidak asing lagi, bahkan selalu ada peningkatan setiap kali pendataan. Penyebab penyakit ini kian meningkat dikarenakan kurangnya kesadaran masyarakat akan penyakit hepatitis dan kurangnya inisiatif untuk berkonsultasi dengan dokter mengenai gejala - gejala yang dirasakan. Dalam penelitian ini dibuat sistem pakar berbasis android untuk mendiagnosis penyaki hepatitis. Metode yang digunakan yaitu metode certainty factor untuk mengatasi masalah ketidakpastian, dan metode forward chaining untuk penelusuran data. Sistem ini berkeja dengan melakukan diagnosis berdasarkan gejala - gejala penyakit yang dirasakan oleh pengguna, lalu dilakukan perhitungan menggunakan certainty factor dan penelusuran data forward chaining. Berdasarkan hasil pengujian menggunakan black box, menunjukan bahwa semua komponen yang diuji mengeluarkan hasil yang diharapkan dan sesuai dengan fungsionalitasnya serta hasil pengujian akurasi dengan pakar ahli penyakit dalam mendapatkan nilai akurasi sebesar $88 \%$. Oleh karena itu sistem ini dapat dikatakan layak untuk digunakan.
\end{abstract}

Kata kunci- Android, Certainty Factor, Forward Chaining, Hepatitis, Sistem Pakar

\section{Pendahuluan}

Hepatitis merupakan penyakit yang diakibatkan adanya kelainan pada hati berupa peradangan hati [1]. Peradangan ditandai dengan meningkatnya kadar enzim hati yang disebabkan karena adanya kerusakan pada membran hati. Faktor penyebab dari infeksi karena virus hepatitis dan bakteri. Virus yang menyebabkan hepatitis misalnya Adenoviruses, Herpes simplex, HIV, Rubella, dan lain-lain. Sedangkan bakteri yang menyebabkan hepatitis misalnya bakteri Salomnella typhi, Salmonella paratyphi, Tuberkulosis, dan Leptosvera. Faktor penyebab noninfeksi terjadi karena konsumsi obat tertentu yang dapat menggangu fungsi hati sehingga menyebabkan hepatitis [2].
Kurangnya inisiatif untuk berkonsultasi dengan dokter mengenai gejala - gejala yang dirasakan menjadi salah satu penyebab bertambah parahnya penyakit hepatitis. World Health Organization (WHO) menyatakan bahwa hepatitis adalah penyakit menular pembunuh terbesar setelah tuberculosis (TBC). World Health Organization (WHO) umumkan jika virus hepatitis merupakan urutan pertama penyakit mematikan dari penyakit hati di seluruh dunia, virus hepatitis mempengaruhi 325 juta orang diseluruh dunia yang menyebabkan 1,4 juta kematian pertahun. Menurut data dari Kemenkes RI (Kementrian Kesehatan Republik Indonesia) pada tahun 2019 Indonesia menduduki peringkat kedua ASEAN pengidap penyakit hepatitis terbesar. 1 dari 10 penduduk Indonesia mengidap penyakit hepatitis $B$, dan 1 dari 4 penduduk Indonesia mengidap hepatitis A dan dinyatakan meninggal dunia karena masalah kanker atau gagal hati.

Pada tahun 2019 sebanyak 30.965 ibu hamil di Indonesia terinfeksi hepatitis B, dan 15.747 bayi baru lahir terinfeksi hepatitis dari ibunya. Tingkat kematian dikarenakan penyakit hepatitis telah mengalami peningkatan. Berdasarkan data dari Pusdatin Kementrian Kesehatan Indonesia angka kematian diakibatkan penyakit hepatitis lebih tinggi dibandingkan mereka yang mengidap HIV/AIDS, salah satu penyebab penyakit ini kian meningkat dikarenakan kurangnya kesadaran masyarakat akan penyakit hepatitis.

Berdasarkan hal tersebut, penulis akan merancang sistem pakar yang mampu melakukan diagnosis yang tepat terhadap penyakit hepatitis. Sistem pakar adalah sistem yang berusaha mengadopsi pengetahuan manusia ke komputer [3]. Sistem pakar merupakan salah satu cabang kecerdasan buatan yang mempelajari bagaimana mengadopsi cara berfikir dan bernalar seorang pakar dalam menyelesaikan suatu permasalahan [4]. Dalam sistem pakar, pengguna dapat berinteraksi dengan komputer dan dapat memecahkan masalah tertentu. Hasil sistem pakar nantinya akan dapat memberikan informasi yang benar 
untuk mendiagnosis secara medis [5]. Sistem pakar yang akan dirancang menggunakan metode certainty factor sebagai nilai kepastiannya dan metode forward chaining sebagai penelusurannya. Metode certainty factor digunakan untuk mengatasi ketidakpastian dalam sistem berbasis aturan. Kelebihan dari metode certainty factor yaitu dapat mengatasi kelemahan sistem pakar, seperti masalah ketidakpastian dalam mendiagnosis suatu penyakit. Metode certainty factor dapat mengolah kepastian/ketidakpastian 2 data, untuk yang lebih dari 2 data perlu melakukannya dengan beberapa kali pengolahan data sehingga keakuratan data dapat terjaga [6]. Metode Certainty Factor memiliki nilai probabilitas lebih tinggi dibandingkan metode Dempster Shafer dan Teorema Bayes sehingga metode Certainty Factor lebih tepat digunakan untuk penelitian ini [7].

Metode forward chaining lebih cocok diterapkan pada suatu aplikasi diagnosis penyakit, dimana pelacakan yang diawali dengan mengumpulkan informasi atau fakta-fakta kemudian fakta tersebut menguji kebenaran suatu diagnosis [8]. Metode forward chaining sangat cocok diterapkan karena pengguna biasanya lebih merasakan gejala yang dirasakan daripada nama penyakit yang dideritanya. Berbeda dengan metode backward chaining yang dimulai dari diagnosis terlebih dahulu yang kemudian mencari fakta-fakta yang mendukung kesimpulan. Berdasarkan dari studi literature, dalam penelitian ini peneliti akan merancang sistem pakar berbasis android untuk diagnosis penyakit hepatitis menggunakan metode Certainty Factor dengan Penelusuran Forward chaining. Penelitian ini dirasa sangat penting untuk memberikan solusi masalah terhadap permasalahan penyakit hepatitis yang dialami masyarakat, selain itu sistem dapat juga dijadikan media pembelajaran masyarakat tentang penyakit hepatitis.

\section{LANDASAN TEORI}

\section{A. Sistem Pakar}

Sistem Pakar adalah Sebuah sistem yang berfungsi untuk membantu menyelesaikan masalah layaknya seorang pakar [6]. Pakar yang dimaksud adalah orang yang mempunyai keahlian yang dapat menyelesaikan masalah yang tidak dapat diselesaikan oleh orang awam. Sebagai contoh, dokter adalah seorang pakar yang mampu mendiagnosis penyakit yang diderita pasien [11]. Sistem pakar dapat diterapkan di android maupun web. Sistem pakar mengadopsi pengetahuan pakar ke komputer, agar dapat menyelesaikan masalah layaknya seorang pakar. Sistem Pakar terdiri dari 3 komponen yaitu, Antar muka pengguna, basis pengetahuan dan mesin inferensi.

\section{B. Certainty Factor}

Metode Certainty Factor digunakan untuk mengatasi kesulitan kepastian. Certainty Factor atau CF merupakan nilai untuk mengukur keyakinan pakar [10]. CF menunjukan ukuran kepastian terhadap suatu fakta atau aturan. Nilai tertinggi CF adalah +1,0 (Pasti benar atau Definitely), dan nilai terendah dalam CF adalah -1,0 (Pasti salah atau Definitely not). Nilai positif merepresentasikan derajat keyakinan, sedangkan nilai negatif mempresentasikan derajat ketidakyakinan.

\section{Forward Chaining}

Forward Chaining adalah algoritma yang dititik beratkan pada pendekatan yang berdasarkan fakta atau informasi. Forward Chaining mulai bekerja dengan data yang tersedia dan menggunakan aturan atau kaidah (klausa IF-THEN) untuk mendapatkan data yang lain sampai mendapatkan suatu kesimpulan [7]. Dalam sistem pakar untuk diagnosa penyakit, forward chaining mengolah masukan-masukan pengguna atau fakta yang berupa gejala. Dari kumpulan fakta tersebut maka dapat dicari suatu kesimpulan untuk mengatasi masalah.

\section{Sistem Operasi Android}

Android merupakan sebuah sistem operasi mobile. Android digunakan untuk perangkat bergerak (mobile device) yang sedang popular saat ini pada beberapa ponsel pintar (smartphone) di dunia maupun di Indonesia. Android menjadi mobile device yang sekarang banyak diminati masyarakat. Pada tahun 2007, Google membentuk Konsorsium Open Handset Alliance (OHA) dengan tujuan mengembangkan android. Konsorsium ini beranggotakan perusahaan-perusahaan ternama di dunia dalam misi pengembangannya, salah satu diantaranya adalah perusahan asal korea selatan yaitu Samsung Electronic [10].

\section{E. Definisi Hepatitis}

Hepatitis merupakan penyakit yang menyerang organ hati manusia. Hati atau liver mengalami peradangan sehingga fungsi hati menjadi terganggu. Jenis penyakit hepatitis:

1) Virus Hepatitis A: prevalensi infeksi yang ditandai dengan tingkatan antiodi dan anti-HAV telah diketahui secara universal dan erat hubungannya dengan standar sanitasi/kesehatan daerah yang bersangkutan Meskipun Virus Hepatitis A ditularkan melalui air dan makanan yang tercemar oleh virus hepatitis $\mathrm{A}$, namun hampir sebagian besar infeksi VHA didapat melalui transmisi endemic atau sporadik yang sifatnya tidak begitu dramatis.

2) Virus Hepatitis B: ditularkan dari orang ke orang melalui (penerima produk darah, pasien hemodialisa, pekerja kesehatan atau terpapar darah). Infeksi VHB terjadi melalui infeksi perinatal atau pada awal masak anak-anak. Infeksi VHB merupakan suatu prises dinamis dengan terjadi interaksi cvirus, hepatosit dan sistem imun manusia.

3) Virus Hepatitis $C$ : memiliki tanda-tanda ringan dibandingan Virus Hepatitis A dan Virus Hepatitis B. tetapi dapat menyebabkan penyakit liver kronis hingga mengalami kanker hati. Hepatitis paling mudah ditularkan melalui rute parenteral seperti penggunaan narkotika suntik, dan transfuse darah [17]. 


\section{F. $U M L$}

UML merupakan kependekan dari Unified Modeling Language. Sederhananya adalah bahasa pemodelan standar untuk pengembangan perangkat lunak dan sistem. Dengan menggunakan UML, dapat dibuat model untuk berbagai jenis aplikasi piranti lunak, dimana piranti lunak tersebut dapat dijalankan pada piranti keras, sistem operasi, jaringan apapun, serta ditulis dalam bahasa pemrograman apapun [16]. Salah satu penerapan diagram UML yaitu ada use case diagram, activity diagram, dan sequence diagram.

\section{METODE PENELITIAN}

Tahapan pada penelitian ini (Lihat Gambar 1), peneliti mencari referensi dengan mempelajari teori-teori yang berhubungan dengan penelitian dan mempelajari metodemetode yang akan dipakai. Selanjutnya Pengambilan data yang dilakukan di RSUD Dr. Margono Soekarjo Purwokerto, data yang di ambil di bagian rekam medik RSUD Dr. Margono Soekrajo Purwokerto, data yang diambil yaitu data pasien yang mengidap penyakit Hepatitis, beserta gejala-gejala yang dialami pasien. Selain itu penulis juga melakukan pengumpulan data dengan wawancara kepada pakar atau ahli penyakit organ dalam hati untuk mendapat nilai certainty factor. Kemudian nilai Certainty Faktor tersebut diolah sampai menghasilkan suatu nilai baru, dari hasil pengolahan tersebut menggunakan metode Certainty Factor, serta dilakukan implementasi metode Forward Chaining untuk mencari rekomendasi akhir.

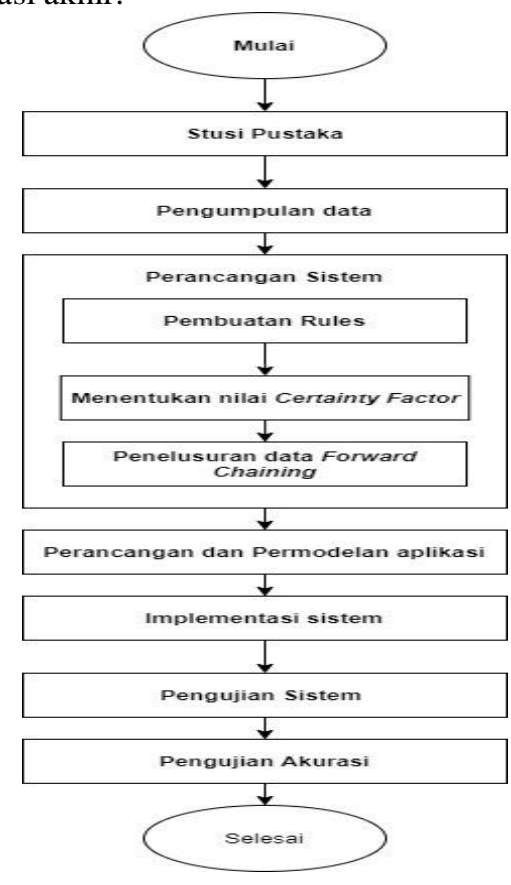

Gambar 1. Tahapan penelitian

\section{PEMBAHASAN}

\section{A. Perancangan Sistem}

1. Pembuatan Rules

Pembuatan rules harus terlebih dahulu dibuat sebelum membangun aplikasi sistem pakar. Dari pengetahuan pakar dilakukan ekstraksi dengan cara membuat block diagram dan depence diagram [12]. Pada tahap ini akan menjelaskan bagaimana langkah-langkah perancangan sistem sebelum membangun sebuah aplikasi sistem pakar.

1) Pembuatan Block Diagram: Pada tahapan ini, dibuat block diagram untuk memperjelas situasi penentuan keputusan penyakit hepatitis berdasarkan gejala-gejala yang terlibat. Dengan adanya block diagram (lihat Gambar 2) maka dapat memudahkan dalam mengetahui urutan kerja dalam mengambil sebuah keputusan.

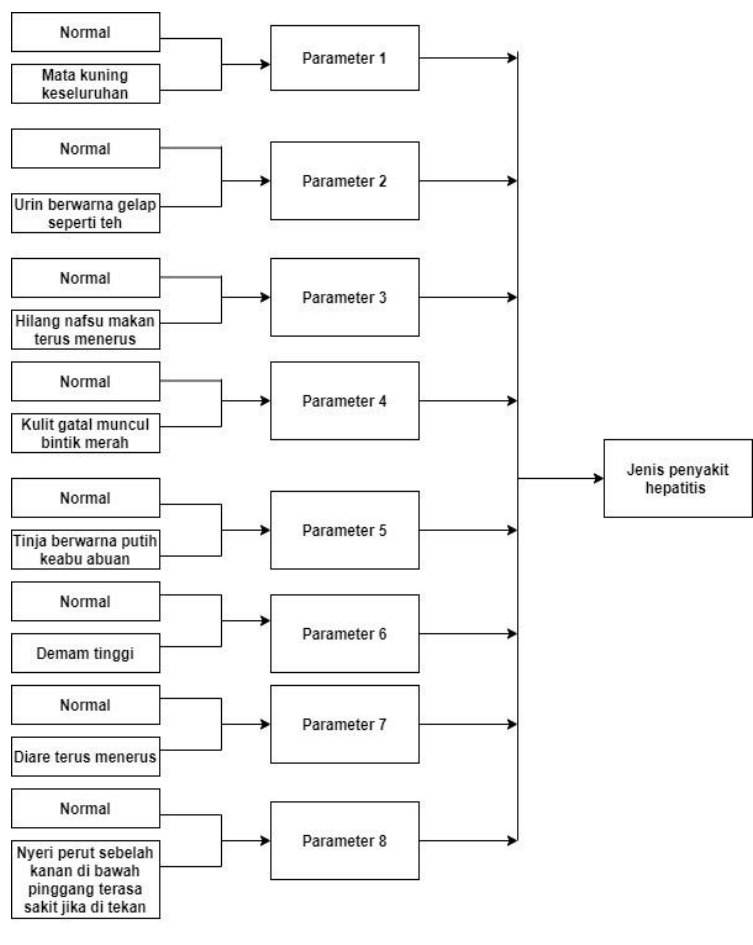

Gambar 2. Block diagram

2) Pembuatan Dependency Diagram: Setelah membuat block diagram, langkah selanjutnya yaitu membuat dependency diagram. Dependency diagram berfungsi untuk menunjukan hubungan atau ketergantungan antara gejala, rules, dan hasil diagnosis. Untuk mempermudah pembuatan dependency diagram dan pembuatan rules, maka dibuat sebuah planning atau rencana yang berisi parameter-pamareter yang didapat dari block diagram dan nilai yang dijadikan pilihan.

Dari Tabel 1 planning dependency diagram dapat dikethui jumlah baris pada rules yang akan dibuat, yaitu 256 baris. Pembuatan dependency diagram berdasarkan pada block diagram yang telah dibuat sebelumnya. 
TABEL I

PLANNING DEPENDENCY DIAGRAM

\begin{tabular}{|l|l|l|}
\hline No. & Kondisi & $\begin{array}{l}\text { Jumlah } \\
\text { Nilai }\end{array}$ \\
\hline 1. & $\begin{array}{l}\text { Parameter 1 (Normal, Mata } \\
\text { menguning keseluruhan) }\end{array}$ & 2 \\
\hline 2. & $\begin{array}{l}\text { Parameter 2 (Normal Urin berwarna } \\
\text { gelap seperti teh) }\end{array}$ & 2 \\
\hline 3. & $\begin{array}{l}\text { Parameter 3 (Normal, Hilang nafsu } \\
\text { makan terus-menerus) }\end{array}$ & 2 \\
\hline 4. & $\begin{array}{l}\text { Parameter 4 (Normal, Kulit gatal } \\
\text { muncul bintik merah) }\end{array}$ & 2 \\
\hline 5. & $\begin{array}{l}\text { Parameter 5 (Normal, Tinja berwarna } \\
\text { putih keabu - abuan) }\end{array}$ & 2 \\
\hline 6. & Parameter 6 (Normal, Demam tinggi) & 2 \\
\hline 7. & $\begin{array}{l}\text { Parameter 7 (Normal, Diare terus } \\
\text { menerus) }\end{array}$ & 2 \\
\hline 8. & $\begin{array}{l}\text { Parameter 8 (Normal, Nyeri perut } \\
\text { sebelah kanan dibawah pinggang } \\
\text { terasa sakit bila di tekan) }\end{array}$ & 2 \\
\hline \multicolumn{2}{|c|}{ Jumlah baris =256 } \\
\hline
\end{tabular}

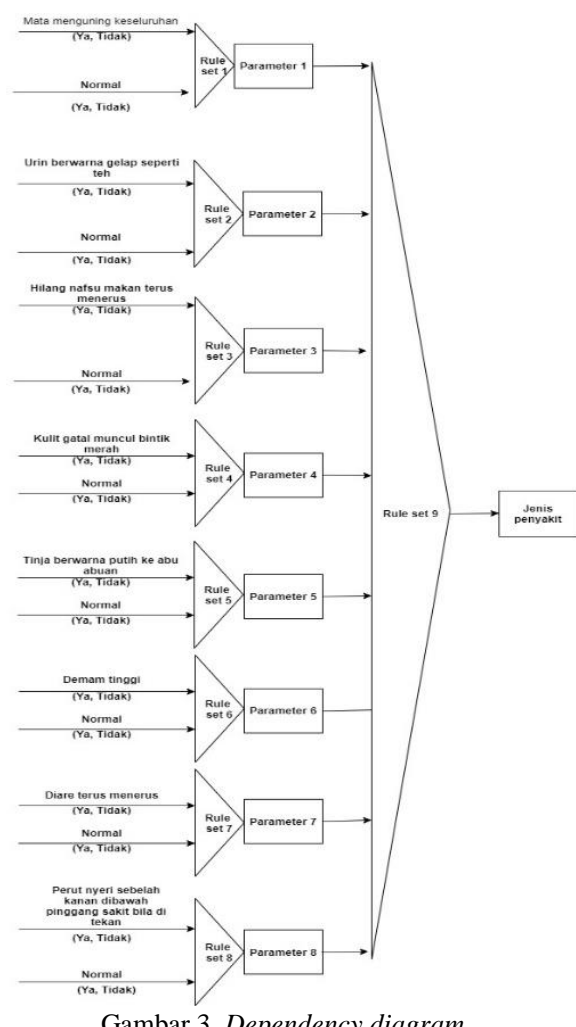

Gambar 3. Dependency diagram

Gambar 3 menunjukan bahwa terdapat delapan Rule set, dimana Rule set 1 sampai 8 merupakan atribut dari setiap parameter pada rules yang akan dibuat, dan Rule set 9 yang merupakan hasil akhir atau diagnosis penyakit hepatitis.

3) Inisialisasi Gejala dan Jenis Penyakit: Tabel 2merupakan inisialisasi gejala-gejala dari penyakit hepatitis. Terdapat 8 gejala dengan kodenya masingmasing.
TABEL II

GEJALA PENYAKIT

\begin{tabular}{|c|c|}
\hline Kode & Gejala \\
\hline G1 & Mata menguning secara keseluruhan \\
\hline G2 & Urin berwarna gelap seperti warna teh \\
\hline G3 & $\begin{array}{l}\text { Hilang nafsu makan secara terus } \\
\text { menerus }\end{array}$ \\
\hline G4 & $\begin{array}{l}\text { Kulit gatal pada tangan muncul bintik } \\
\text { merah }\end{array}$ \\
\hline G5 & Tinja berwarna putih keabu - abuan \\
\hline G6 & Demam tinggi \\
\hline G7 & Diare jangka panjang \\
\hline G8 & $\begin{array}{l}\text { Nyeri perut sebelah kanan dibawah } \\
\text { iga pinggang terasa sakit bila di tekan }\end{array}$ \\
\hline
\end{tabular}

Tabel 3 merupakan inisialisasi jenis-jenis penyakit hepatitis. Terdapat 3 jenis penyakit kodenya masingmasing. Tujuan melakukan inisialisasi untuk memudahkan dalam pembuatan rule dan implementasi pada kode program.

TABEL III

JENIS PENYAKIT

\begin{tabular}{|l|l|}
\hline Kode & Jenis Penyakit \\
\hline P1 & Hepatitis A \\
\hline P2 & Hepatitis B \\
\hline P3 & Hepatitis C \\
\hline
\end{tabular}

\section{Menentukan Nilai Certainty Factor}

Pada tahap ini, setelah menentukan rule langkah selanjutnya yaitu menghitung nilai certainty factor. Perhitungan nilai certainty factor menggunakan nilai MB dan MD yang didapatkan dari wawancara dengan pakar ahli hepatitis. Adapun tabel nilai certainty factor dapat dilihat pada Tabel 4

TABEL IV

NILAI CERTAINTY FACTOR

\begin{tabular}{|l|l|l|l|}
\hline Jenis Penyakit & Gejala & MB & MD \\
\hline Hepatitis A & G1 & 0,7 & 0,1 \\
\hline & G2 & 0,7 & 0,1 \\
\hline & G3 & 0,5 & 0,1 \\
\hline & G5 & 0,75 & 0,05 \\
\cline { 2 - 4 } & G7 & 0,7 & 0,1 \\
\hline Hepatitis B & G1 & 0,7 & 0,05 \\
\cline { 2 - 4 } & G2 & 0,6 & 0,1 \\
\cline { 2 - 4 } & G3 & 0,55 & 0,05 \\
\cline { 2 - 4 } & G6 & 0,75 & 0,05 \\
\cline { 2 - 4 } & G7 & 0,7 & 0.05 \\
\hline Hepatitis C & G1 & 0,75 & 0,05 \\
\cline { 2 - 4 } & G2 & 0,75 & 0,1 \\
\hline & G3 & 0,5 & 0,15 \\
\hline & G4 & 0,6 & 0,1 \\
\hline & G8 & 0,75 & 0,05 \\
\hline
\end{tabular}


1) Menghitung Nilai $M B$ dengan MD: Pada perhitungan nilai certainty factor ini menggunakan salah satu dari 256 rule sebagai contoh, rule yang digunakan yaitu rule ke 147. Berikut perhitungan nilai certainty factor setiap gejala menggunakan peramaan 1 :

$$
\mathrm{CF}[\mathrm{h} . \mathrm{e}]=\mathrm{MB}[\mathrm{h}, \mathrm{e}]-\mathrm{MD}[\mathrm{h}, \mathrm{e}]
$$

Nilai certainty factor pada setiap gejala dapat diperoleh dengan mengurangi nilai MB dengan MD.

$$
\begin{aligned}
& C F[\mathrm{P} 1, \mathrm{G} 2]=0,7-0,1=0,6 \\
& C F[\mathrm{P} 1, \mathrm{G} 5]=0,75-0,1=0,7 \\
& C F[\mathrm{P} 2, \mathrm{G} 2]=0,6-0,1=0,5 \\
& C F[\mathrm{P} 3, \mathrm{G} 2]=0,75-0,1=0,65 \\
& C F[\mathrm{P} 3, \mathrm{G} 8]=0,75-0,05=0,7
\end{aligned}
$$

2) Menghitung Nilai Certainty Factor Kombinasi Evidence: Pada rule ke 147 memiliki gejala-gejala yaitu G2, G5 dan G8 dan diagnosis jenis penyakit P1, P2, P3. Langkah pertama yaitu menghitung kombinasi setiap gejala-gejala sesuai dengan jenis penyakitnya menggunakan persamaan 2 dan 3 [17]:

$$
C F=C F[h, e]_{1}+C F[h, e]_{2} \times\left(1-C F[h, e]_{1}\right)
$$

Pada rule ke 147 , jenis penyakit P1 memiliki gejala G2 dan G5, jenis penyakit P2 memiliki gejala G2, jenis penyakit P3 memiliki gejala G2 dan G8. Maka hitung kombinasi setiap gejala satu-persatu.

$$
\begin{aligned}
& C F[\mathrm{P} 1, \mathrm{G} 2]=0,6 \\
& C F[\mathrm{P} 1, \mathrm{G} 5]=0,7 \\
& C F[\mathrm{P} 1, \mathrm{G} 2 \wedge \mathrm{G} 5]=0,6+0,7 *(1-0,6)=0,88 \\
& C F[\mathrm{P} 2, \mathrm{G} 2]=0,5 \\
& C F[\mathrm{P} 3, \mathrm{G} 2]=0,65 \\
& C F[\mathrm{P} 3, \mathrm{G} 8]=0,7 \\
& C F[P 3, G 2 \wedge \mathrm{G} 8]=0,65+0,7 *(1-0,65)=0,895
\end{aligned}
$$

Dari perhitungan diatas maka dapat disimpulkan bahwa rule ke 147 memiliki jenis penyakit dengan nilai certainty factor terbesar yaitu P3 atau hepatitis C.

3) Penelusuran Forward Chaining: Pada tahap ini dilakukan penelusuran data menggunakan forward chaining untuk perancangan identifikasi hepatitis. Penelusuran dilakukan setelah nilai certainty factor di dapatkan. Berdasarkan rule 147, maka disusun daftar aturan yang sesuai dengan alur metode forward chaining yaitu runtut maju.

Berikut implementasi forward chaining rule 147:

IF G2 AND G5 AND G8 THEN P3 = 0,895 AND P1 = 0,88 AND $\mathrm{P} 2=0,5$

\section{B. Perancangan dan Pemodelan Aplikasi}

Pada tahap ini, setelah merancang prototype dasar kasus secara lengkap kemudian pengembangan sistem dilanjutkan dengan merancang dan membuat bahasa pemodelan. Tahapan meliputi perancangan use case diagram, activity diagram, sequence diagram dan antar muka (interface).

1) Use case diagram: menggambarkan hubungan pengguna/aktor dengan proses sistem (kebutuhan sistem dari sudut pandang pengguna). Adapun use case diagram pada sistem pakar ini dapat dilihat pada Gambar 4.

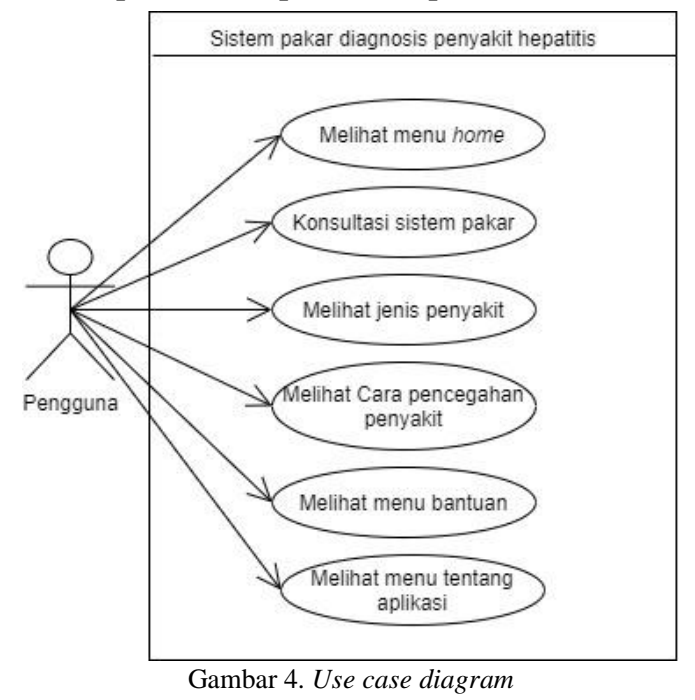

2) Activity Diagram: Activity diagram yaitu menggambarkan aliran aktivitas dari sistem yang sedang dirancang. Bagaiman sistem tersebut mulai dan diakhiri, activity diagram pada sistem pakar ini dapat dilihat pada Gambar 5.

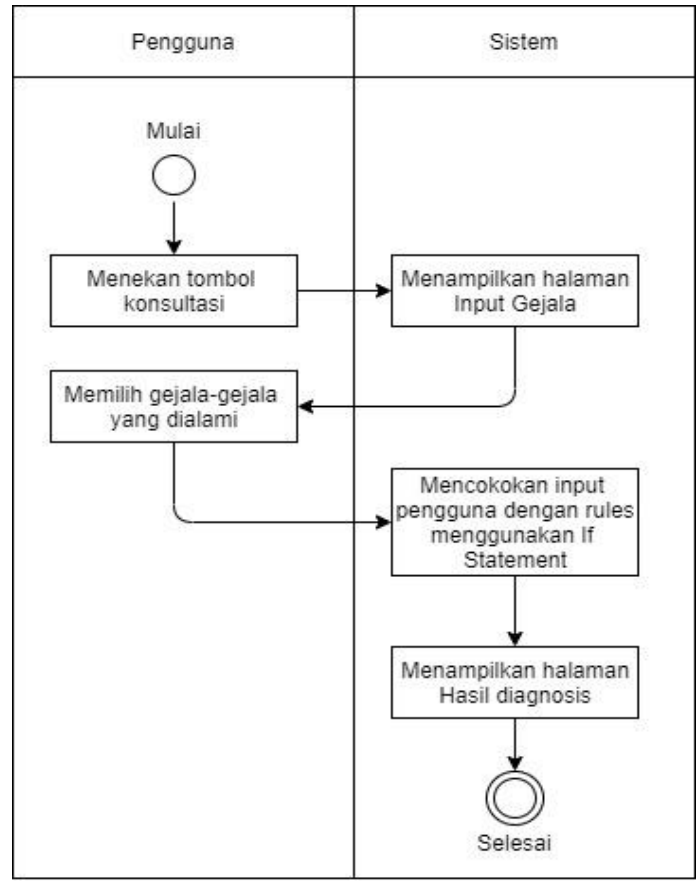

Gambar 5. Activity diagram konsultasi

3) Sequence Diagram: Sequence diagram menggambarkan interaksi atau hubungan antar objek yang disusun pada sebuah urutan atau rangkaian waktu. Adapun sequence diagram pada sistem pakar ini dapat dilihat pada Gambar 6. 


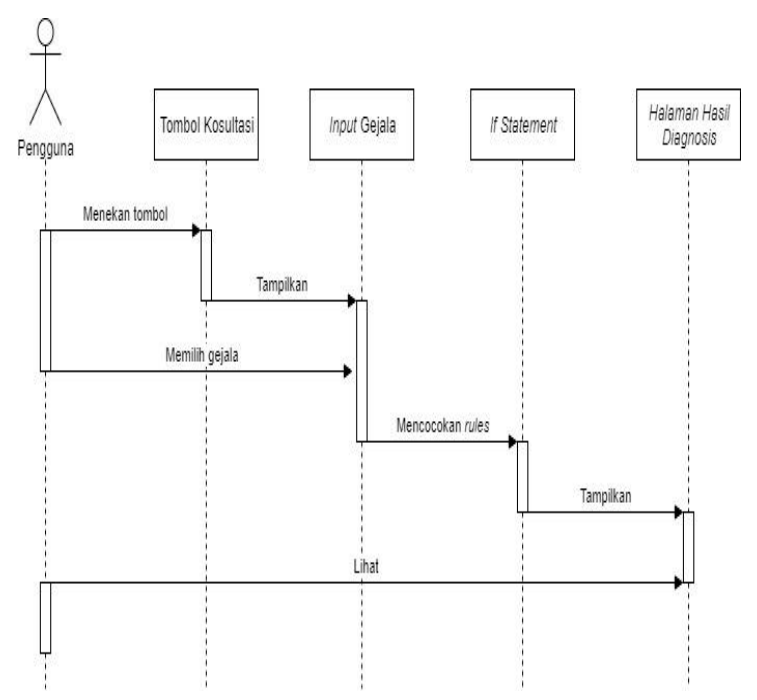

Gambar 6. Squance diagram konsultasi

4) Desain Interface: Pada tahap ini penulis merancang desain antar muka (interface) aplikasi sistem pakar diagnosis penyakit hepatitis. Perancangan desain antar muka ini akan menjadi acuan dalam membangun aplikasi yang sesungguhnya. Berikut merupakan beberapa desain rancangan interface aplikasi.

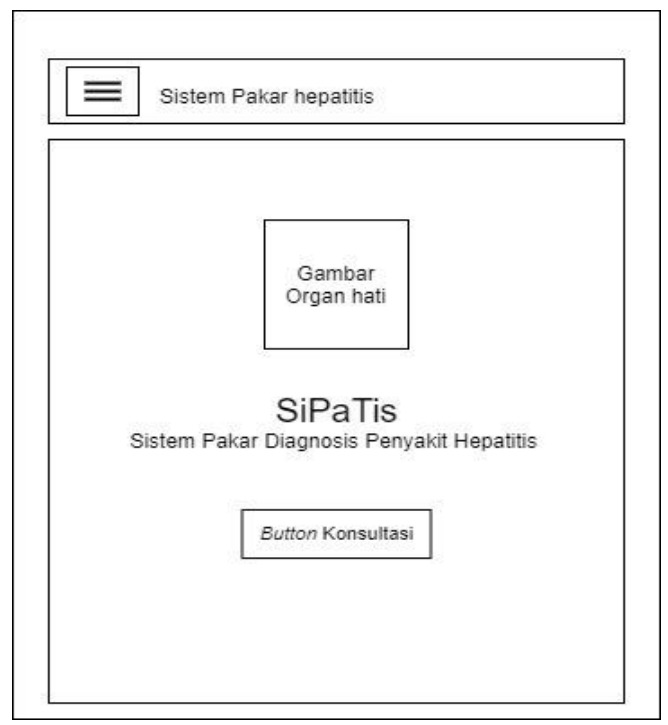

Gambar 7. Rancangan halaman home

Gambar 7 merupakan rancangan halaman home atau halaman utama yang akan ditampilkan ketika pengguna pertama kali membuka aplikasi. Terdapat logo dan button konsultasi untuk berpindah ke halaman konsultasi.

Pada gambar 8 terdapat menu ceklis sebagai pilihan yang dapat dipilih pengguna untuk menentukan gejalagejala. Terdapat juga button submit untuk mengakhiri sesi input gejala dan melanjutkan ke halaman selanjutnya

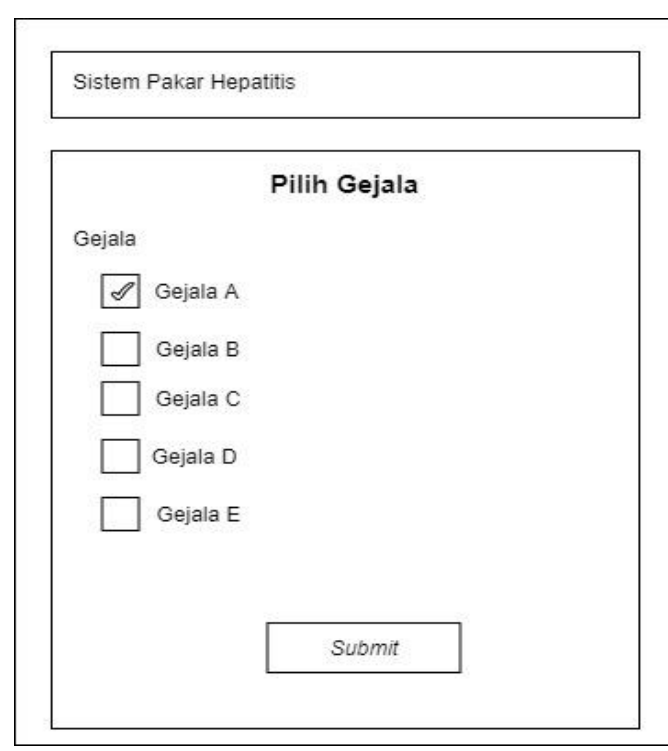

Gambar 8. Rancangan halaman input gejala

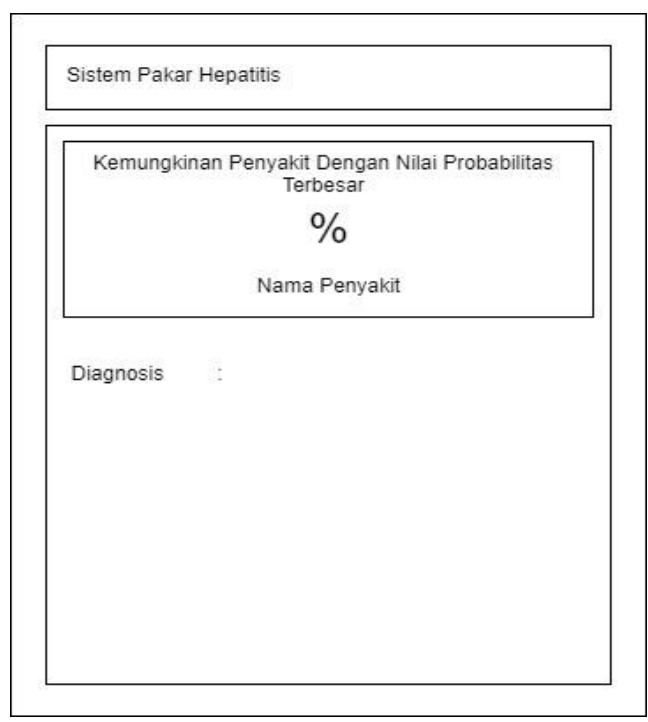

Gambar 9. Rancangan halaman hasil konsultasi

Rancangan hasil konsultasi merupakan hasil dari konsultasi yang telah pengguna lakukan. Pada tampilan ini berisi informasi hasil akhir berupa gejala-gejala yang dipilih sebelumnya, jenis penyakit yang diderita, dan prosentase nilai keyakinan pada setiap jenis penyakitnya. Rancangan menu hasil konsultasi dapat dilihat pada gambar 9 .

\section{Implementasi Sistem}

Pada tahap ini, akan menjelaskan hasil output aplikasi sistem pakar diagnosis penyakit hepatitis yang berupa tampilan atau interface. Setiap tampilan atau interface memiliki layout yang terhubung dengan kelas java. Berikut merupakan tampilan dari aplikasi sistem pakar diagnosis penyakit hepatitis. 


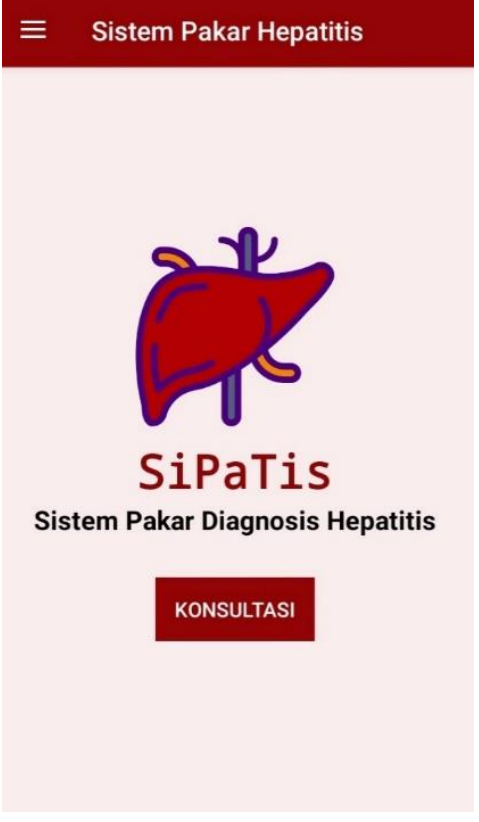

Gambar 10. Halaman home

Gambar 10 merupakan halaman pertama ketika pengguna membuka aplikasi sistem pakar. Aplikasi yang dirancang menggunakan warna cokelat muda sebagai latar belakang, dan coklat tua sebagai header aplikasi.

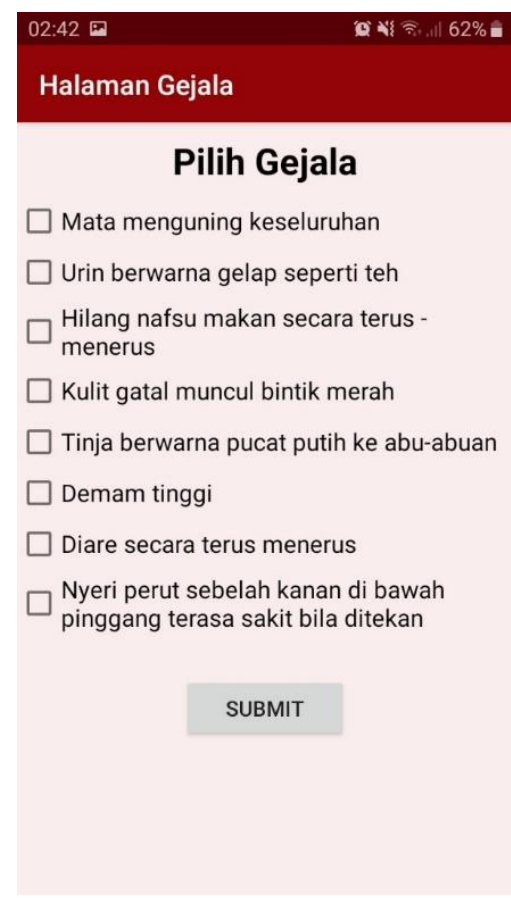

Gambar 11. Halaman input gejala

Gambar 11 merupakan tampilan input gejala penyakit hepatitis. Terdapat delapan gejala.

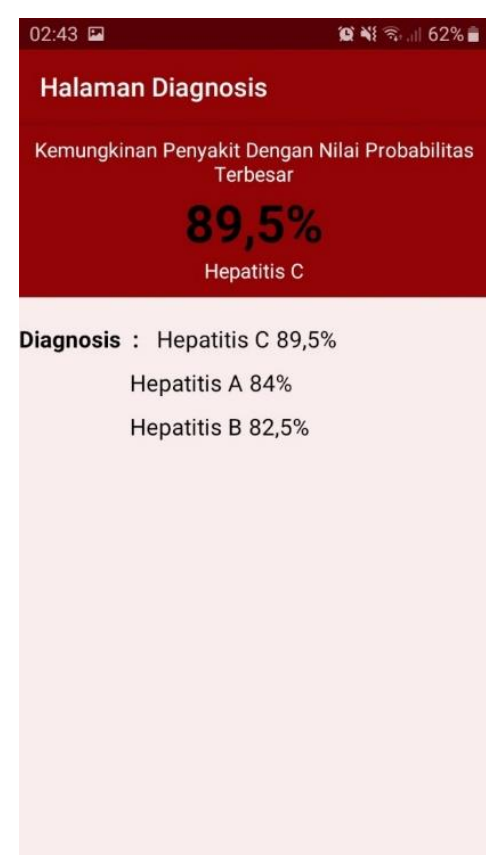

Gambar 12. Halaman hasil konsultasii

Gambar 12 merupakan halaman hasil akhir dari sesi konsultasi yang dilakukan pengguna. Pada halaman tersebut, menampilkan diagnosis penyakit yang dialami pengguna. Setiap diagnosis jenis penyakit memiliki nilai certainty factor masing-masing, yang yang terbesar akan ditampilkan paling atas, sehingga pengguna lebih mudah dalam memastikan jenis penyakit yang dialaminya.

\section{Pengujian Sistem}

Pengujian sistem dilakukan untuk menentukan apakah apilkasi yang telah dibuat berjalan sesuai dengan fungsionalitasnya atau tidak. Pada tahap pengujian sistem, peneliti menggunakan metode pengujian sistem black box yang mengevaluasi fungsionalitas dan tampilan luar sistem. Berdasarkan pengujian sistem dengan 10 responden, semua sistem berjalan dan berfungsi semestinya.

\section{E. Pengujian Akurasi}

Pada tahap ini dilakukan pengujian akurasi untuk mengetahui apakah sistem yang dibangun layak untuk mengidentifikasi penyakit hepatitis. Dari 256 rule yang telah dibuat, diambil 150 rule secara acak untuk diuji kebenaran hasil diagnosis dengan pendapat pakar penyakit dalam. Untuk hasil akhir diagnosis penyakit pada setiap rule dipilih yang memiliki nilai certainty factor terbesar. Dari 150 rule yang diuji, 132 rule dinyatakan sesuai dengan pendapat pakar dan 18 sisanya dinyatakan tidak sesuai. Pengujian akurasi menggunakan confusion matrix:

$$
\text { Accuracy }=\frac{T P+T N}{T P+T N+F P+F N} \times 100 \%
$$

Keterangan:

TP $($ True Positive $)=$ jumlah kasus yang diidentifikasi positif atau benar untuk data uji positif, FP (False Positive) 
$=$ jumlah kasus yang diidentifikasi negatif atau salah untuk data uji positif, TN (True Negative) = jumlah kasus yang diidentifikasi positif atau benar untuk data iji negatif, FN (False Negative $)=$ jumlah kasus yang diidentifikasi negatif atau salah untuk data uji negatif [18].

TABEL V

KALKULASI AKURASI

\begin{tabular}{|l|l|l|l|l|}
\hline Jenis Identifikasi & TP & TN & FP & FN \\
\hline Diagnosis Penyakit Gizi & 132 & 0 & 18 & 0 \\
\hline
\end{tabular}

Tabel 5 merupakan tabel kalkulasi yang berisi nilai pada setiap variable yang akan dihitung menggunakan rumus akurasi confusion matrix. Jadi didapatkan perhitungan akurasi dari sistem ini yaitu:

$$
\begin{aligned}
\text { Accuracy } & =(132+0) /(132+18+0+0) \times 100 \% \\
& =132 / 100 \times 100 \% \\
& =88 \%
\end{aligned}
$$

\section{KESIMPULAN}

Berdasarkan hasil penelitian, perancangan, dan implementasi sistem, maka dapat disimpulkan sebagai berikut:

1. Metode certainty factor dan forward chaining dapat diimplementasikan dalam sistem pakar untuk diagnosis hepatitis berdasarkan gejala - gejala yang di input pengguna. Dibuktikan dengan adanya akurasi dengan pakar. Dari 150 sampel rule yang dipilih secara acak, 132 dinyatakan benar dan 18 rule dinyatakan tidak sesuai, sehingga dari pengujian tersebut didapatkan nilai akurasi sebesar $88 \%$.

2. Setelah melakukan pengujian sistem dengan black box, sistem pakar yang dirancang layak untuk digunakan, karena dari 10 data kuisioner yang diberikan kepada masyarakat menunjukan bahwa komponen yang di uji menampilkan keluaran yang diharapkan dan sesuai dengan fungsionalitasnya.

\section{REFERENSI}

[1] M. Neshat, M. Sargolzaei, A. N. Toosi, and A. Masoumi, "Hepatitis Disease Diagnosis Using Hybrid Case Based Reasoning and Particle Swarm Optimization," vol. 2012, 2012.

[2] A. T. Novarina and E. Santoso, "Sistem Pakar Diagnosis Penyakit Hepatitis Menggunakan Metode Dempster Shafer," vol. 2, no. 6, 2018.

[3] R. A. Soltan and M. Z. Rashad, "Diagnosis of Some Diseases in Medicine via computerized Experts," vol. 5, no. 5, pp. 79-90, 2013

[4] V. Kemala, B. Irawan, and M. Nasrun, "Rancang Bangun Aplikasi Sistem Pakar Untuk Diagnosis Penyakit Kulit dan Kelamin Berbasis Smartphone Android,” vol. 2, no. 2, pp. 3568-3574, 2015.

[5] H. Susilo, "Sistem Pakar Metode Forward Chaining Dan Certainty Factor Untuk Mengidentifikasi Penyakit Pertusis Pada Anak Herman," vol. I, no. 2, pp. 185-194, 2018.

[6] P. Syahromi, "Sistem Pakar Mendiagnosa Penyakit Leptospirosis Menggunakan Metode Certainty Factor Dengan Penelusuran Forward Chaining," vol. 3, no. 1, pp. 108-112, 2016.

[7] I. Akil, P. Studi, M. Administrasi, and J. Timur, "Analisa Metode Fotrward Chaining dan Backward Chaining," vol. 13, no. 1, pp. 35-42, 2017.
[8] S. Nurajizah, M. Saputra, M. Informatika, and S. Informasi, "Sistem pakar diagnosa penyakit kulit kucing dengan metode forward chaining," vol. 14, no. 1, pp. 7-14, 2018.

[9] Z. Wele and E. Mulyanto, "Penerapan metode forward chaining dengan teknik representasi Rule based reasoning untuk fiagnosa kerusakan mobil berbasis android," pp. 1-7.

[10] L. Septiana, "Perancangan sistem pakar diagnosa penyakit ispa," vol. XIII, no. 2, pp. 1-8, 2016.

[11] S. Sibagariang, "Sistem Pakar Diagnosa Penyakit Sapi Dengan Metode Certainty Factor Berbasis Android," vol. IV, no. 2, pp. 3539, 2015.

[12] A. Andriani, Pemograman Sistem Pakar. Yogyakarta: MediaKom, 2016.

[13] F. F. Rohman, A. Fauzijah, and S. Pakar, "Sistem pakar pekembangan anak," vol. 6, no. 1, pp. 1-23, 2008.

[14] O. D. Nurhayati, K. T. Martono, P. Studi, S. Komputer, F. Teknik, and U. Diponegoro, "Pengembangan aplikasi sistem cerdas untuk menentukan peminatan jurusan di universitas diponegoro bagi siswa sekolah menengah atas," vol. 3, no. 2, pp. 295-301, 2015.

[15] J. F. Dimarzio, Beginning Android Programming with Android Studio. Indianapolish: John Wiley \& Sons, 2017.

[16] H. Wahyudi, "Hepatitis," 2017.

[17] S. A. Kurniawati, T. H. Karjadi, and R. A. Gani, "Faktor - Faktor yang Berhubungan dengan Kejadian Hepatitis C pada Pasangan Seksual Pasien Koinfeksi Human Immunodeficiency Virus dan Virus Hepatitis C,” vol. 2, no. 3, pp. 133-139, 2015. 